\title{
Comparison of dissolution methods for multi-element analysis of some plant materials used as bioindicator of sulphur and heavy metal deposition determined by ICP-AES and ICP-MS
}

\author{
R. Pöykiö ${ }^{*}, 1, H$. Torvela ${ }^{1}$, P. Perämäki², T. Kuokkanen² and H. Rönkkömäki² \\ ${ }^{1}$ Meri-Lappi Institute, Centre for Environmental Technology, University of Oulu, \\ Tietokatu 6, FIN-94600, Kemi, Finland \\ ${ }^{2}$ University of Oulu, Department of Chemistry, P.O. Box 3000, FIN-90014, University of Oulu, Finland
}

\begin{abstract}
Most analytical methods for trace element determination in plant material require decomposition of the sample. Sample decomposition procedures play an important role in ensuring that chemical analysis gives correct results. This is especially important in the determination of trace elements in plant material for environmental studies because, as a rule, plant material is not homogeneous and usually contains variable matrices. In this paper microwave digestion procedures using $\mathrm{HNO}_{3}, \mathrm{HNO}_{3}+\mathrm{H}_{2} \mathrm{O}_{2}$, $\mathrm{HNO}_{3}+\mathrm{HClO}_{4}$, HF mixtures and dry ashing $+\mathrm{HF}$ were investigated for the analysis of $\mathrm{Al}, \mathrm{Ca}, \mathrm{Cr}, \mathrm{K}, \mathrm{Mg}, \mathrm{Mn}, \mathrm{Zn}, \mathrm{S}, \mathrm{Pb}, \mathrm{V}, \mathrm{Cu}$, $\mathrm{Cd}$, Co and Ni by ICP-AES or ICP-MS from pine needle samples. Reference samples BCR CRM 100 (Spruce Needles), BCR CRM 101 (Beech Leaves) and HUMH2 (Organic surface soil) were used to test the dissolution methods. The results showed that the sample digestion procedure is critical step for obtaining accurate results. Losses of volatile metals were notable in many cases when dry ashing was used.
\end{abstract}

Key words. Plant material - dissolution methods - elemental analysis - ICP-AES - ICP-MS - CRMs - microwave oven.

\section{Introduction}

Many analytical methods for trace element determination in plant material require decomposition of the sample. Hence, the efficiency of the mineralization procedure is of great importance for obtaining correct results. In the last two decades, great progress has been made in analytical instrumentation, but sample preparation is still the major factor contributing to the uncertainty of the final results. This is especially important in the determination of trace elements in environmental studies.

Bioindicators represent a complementary tool for environmental monitoring systems, and can also overcome some of the shortcomings associated with the direct measurement of pollution. Bioindicators provide a complementary tool for environmental monitoring systems, and may overcome some of the shortcomings involved in measuring environmental pollution directly. The determination of sulphur and heavy metals in plants is an integral part of many environmental studies in Finland. Pine needles and mosses have proved to be suitable air quality indicators for pollutants, especially for sulphur. In Finland the sulphur concentration of pine needles and lichens has been determined in several urban and rural environments, and numerous studies have shown correlation between the sulphur concentrations of pine needles and emissions from anthropogenic sources [1-4]. In Finland pine needles are widely used as a bioindicator of sulphur and heavy metal deposition in the areas around pulp and paper mills, as well as in the vicinity of steelworks.

The analysis of sulphur in plant material has been a topic of discussion for several years. There are several methods available for this purpose, such as turbidimetric [5-7] and Xray fluorescence spectrometry [8-10]. Combustion techniques coupled with either photometric or titrimetric quantitation of the evolved sulphur have been used to a limited extent [10-14]. Inductively coupled plasma atomic emission spectrometry (ICP-AES) has become an established analytical tool for multi-element analysis since it was first introduced by Greenfield in 1964 [15] and Wendt et al. in 1965 [16]. Good detection limits, a large linear dynamic range, relative freedom from chemical inter-element interferences, simultaneous multielement capability and, above all, its high sample throughput make ICP-AES a powerful analytical tool for many applications $[17,18]$. ICP-AES generally requires sample presentation as a liquid. This involves the destruction of organic material by wet or dry oxidation. Mixtures such as $\mathrm{HNO}_{3}+\mathrm{H}_{2} \mathrm{O}_{2}, \mathrm{HNO}_{3}+\mathrm{HClO}_{4}$ or $\mathrm{HNO}_{3}$ alone were proposed for sample solubilisation for multi-element ICPAES analysis already many years ago [17,18]. 


\section{Background and objectives}

In Finland a new Environmental Protection Act has been in force since 1.3.2000. Environmental legislation requires the operator to be aware of the amount and composition of the emissions, as well as of the efficiency of the abatement methods/equipment used, and also of the impacts on the environment caused by the operations of the pollutant source.

In Finland, pine needles, lichens and moss are widely used to provide an index of air pollution in the vicinity of pulp and paper mills. Niskanen and Witick [19] used $\mathrm{HNO}_{3}$ for dissolution of moss samples and AAS for the determination of sulphur and heavy metals. Vanhatalo [20] used Xray fluorescence analysis for the analysis of sulphur in pine needles, and Tynnyrinen [21] used ion chromatography for sulphur determination of pine needles. Combustion techniques coupled with either photometric or titrimetric quantitation of the evolved sulphur have also been used to a limited extent [22-25].

Nowadays ICP-AES is widely used for multi-element analysis. Determination of sulphur concentrations in conifer needles using ICP-AES is well documented in Finnish SFS standards, but there is still no standard for heavy metal analysis [26]. As a result, wide range of dissolution and determination methods have been used. This prompted us to carry out a study on the sulphur and heavy metal analysis of plant material in order to quantify the effects of digestion methods involving different acid mixtures on the results obtained by ICP-AES and ICP-MS. This study is a part of a major project focusing on the effects of the forest, metal and mining industries on the environment in Finland, and on the use of plants as a bioindicator of sulphur and heavy metal deposition.

\section{Experimental}

\section{Instrumentation}

The Leco ELTRA CS 500 was used only for sulphur analysis. ICP-AES system Thermo Jarrell Ash Corporation IRIS ADVANTAGE (Duo High Resolution) with concentric nebulizer (Meinhard) or the Perkin Elmer SCIEX ELAN 5000 Inductively coupled Plasma-Mass Spectrometry (ICP-MS) with a cross-flow nebulizer and $\mathrm{Ni}$-cones were used for the multi-element analysis.

The instrumental running parameters for ICP-AES are given in table I, and for ICP-MS in table II.

\section{Materials}

The study was based on three certified standard reference materials (SRMs) BCR CRM 100 (Spruce Needles), BCR CRM 101(Beech Leaves), HUMH2 (Organic surface soil), and on two uncertified pine needle samples "Kemi" and "Tornio" representing two different contaminant levels.
Table I. ICP-AES running parameters.

\begin{tabular}{lc}
\hline$R F$-power & $950 \mathrm{~W}$ \\
\hline Argon torch gas flow & $18 \mathrm{l} / \mathrm{min}$ \\
Argon auxiliary gas flow & $0.51 / \mathrm{min}$ \\
Argon nebulizer gas flow & $0.61 / \mathrm{min}$ \\
Detector temperature & $-41.5^{\circ} \mathrm{C}$ \\
\hline
\end{tabular}

Table II. ICP-MS running parameters.

\begin{tabular}{lc}
\hline$R F$-power & $1000 \mathrm{~W}$ \\
\hline Argon torch gas flow & $15 \mathrm{l} / \mathrm{min}$ \\
Argon auxiliary gas flow & $0.82 \mathrm{l} / \mathrm{min}$ \\
Argon nebulizer gas flow & $0.695 \mathrm{l} / \mathrm{min}$ \\
\hline
\end{tabular}

\section{Reagents}

The following reagents were used: $\mathrm{HNO}_{3}$ (Suprapur, Merck, $65 \%$ ), $\mathrm{HClO}_{4}$ (Suprapur, Merck, $40 \%$ ), HF (Suprapur, Merck, $40 \%$ ), $\mathrm{H}_{2} \mathrm{O}_{2}$ (Merck, $30 \%$ ), $\mathrm{H}_{2} \mathrm{O}$ (Ultrapur) and $\mathrm{V}_{2} \mathrm{O}_{5}$ (Leco Corporation).

\section{Procedure for the heavy metals and sulphur determination by ICP-AES or ICP-MS}

The samples were digested with different acid mixtures using US EPA method 3051 [27]. The plant samples materials were dried at $70{ }^{\circ} \mathrm{C}$ for 5 days in a Memmert B-40 oven and ground $(<2 \mathrm{~mm})$ in a Fritzch P-14 mill. For dissolution, $250 \mathrm{mg}$ of plant sample was weighed into the microwave oven digestion vessel (PFA, $100 \mathrm{ml}$ ) and dissolved in $10 \mathrm{ml} \mathrm{HNO}_{3}\left(\right.$ abbr. $\left.\mathrm{HNO}_{3}\right)$ or $10 \mathrm{ml} \mathrm{HNO}_{3}+2 \mathrm{ml}$ $\mathrm{H}_{2} \mathrm{O}_{2}$ (abbr. $\mathrm{HNO}_{3}+\mathrm{H}_{2} \mathrm{O}_{2}$ ). In the $\mathrm{HNO}_{3}+\mathrm{HClO}_{4}$ digestion procedure (abbr. $\mathrm{HNO}_{3}+\mathrm{HClO}_{4}$ ), the sample was first dissolved in $10 \mathrm{ml} \mathrm{HNO}_{3}+3 \mathrm{ml} \mathrm{HClO}_{4}$ and, after evaporation to dryness, the residue was dissolved in $20 \mathrm{ml} \mathrm{HNO}_{3}$ and diluted to $50 \mathrm{ml}$ with $\mathrm{H}_{2} \mathrm{O}$. In the $\mathrm{HF}$ digestion procedure (abbr. HF), the sample was first dissolved in $10 \mathrm{ml} \mathrm{HNO}_{3}$ and $2 \mathrm{ml} \mathrm{HF}$ was then added. All the dissolutions were performed with a Milestone MLS-1200 Mega computer controlled microwave oven (14 closed PFA vessels), with the digestion program. Step 1: power $250 \mathrm{~W}$, time $1 \mathrm{~min}$; Step 2: power $\mathrm{O} \mathrm{W}$, time $2 \mathrm{~min}$, Step 3: power $250 \mathrm{~W}$, time $5 \mathrm{~min}$, Step 4: power $400 \mathrm{~W}$, time $5 \mathrm{~min}$, Step 5: power $600 \mathrm{~W}$, time $5 \mathrm{~min}$; Step 6: power $250 \mathrm{~W}$, time $5 \mathrm{~min}$. In the dry ashing digestion procedure (abbr. $\mathrm{HF}(\mathrm{DAC})$ ), the sample was first ashed in a small crucible at $450{ }^{\circ} \mathrm{C}$ in a Labotherm L9 laboratory furnace, and the residue was then dissolved in $10 \mathrm{ml} \mathrm{HNO}_{3}$ and $2 \mathrm{ml} \mathrm{HF}$.

\section{Procedure for the sulphur determination by Leco}

The dried and ground sample $(0.20 \mathrm{~g})$ was combusted with $\mathrm{V}_{2} \mathrm{O}_{5}$ as combustion accelerator in a stream $(300 \mathrm{ml} / \mathrm{min})$ of 
pure oxygen at $1350{ }^{\circ} \mathrm{C}$ for approximately $2 \mathrm{~min}$. The evolved $\mathrm{SO}_{2}$ was detected and measured in an IR cell after removal of water.

\section{Results and discussion}

SRMs are useful in assessing overall method accuracy and in evaluating potential method bias, because they are available in the form of homogeneous materials and their element concentrations are certified using more than one analytical technique. The choice of reference materials BCR CRM 100 and BCR CRM 101 was based on their different sulphur concentrations (2690 mg/kg and $1700 \mathrm{mg} / \mathrm{kg}$ respectively), as well as on the fact that they represent either needle or leaf matrices. The choice of reference material HUMH2 made by Finnish Forest Research Institute was based on its constituent elements and because of the lack of a suitable needle sample containing heavy metals.

Pine needle sample "Kemi" was collected in the area around a pulp and paper mill complex in Kemi. The complex releases large amounts of sulphur dioxide $\left(\mathrm{SO}_{2}\right)$ and malodorous sulphur compounds, also called TRS compounds, such as hydrogen sulphide $\left(\mathrm{H}_{2} \mathrm{~S}\right)$, methyl mercaptane $\left(\mathrm{CH}_{3} \mathrm{SH}\right)$, and methyl sulphides $\left[\left(\mathrm{CH}_{3}\right)_{2} \mathrm{~S}\right.$ and $\left.\left(\mathrm{CH}_{3}\right)_{2} \mathrm{~S}_{2}\right]$ into the ambient air, and $\mathrm{Ca}, \mathrm{K}$ and $\mathrm{S}$ are main components in metal deposition derived from the pollutant source. Pine needle sample "Tornio" was collected from an area heavily polluted by metals such as $\mathrm{Cr}, \mathrm{Ni}, \mathrm{V}, \mathrm{Cu}, \mathrm{Co}, \mathrm{Cd}$ and $\mathrm{Mn}$ emitted into the atmosphere in the vicinity of the ferrochrome and steel works at Tornio.

Results of the elemental analysis of $\mathrm{Al}, \mathrm{Ca}, \mathrm{K}, \mathrm{Mg}, \mathrm{Mn}$, $\mathrm{Zn}$ and $\mathrm{S}$ in reference samples BCR CRM 100 (Spruce Needles) and BCR CRM 101 (Beech Leaves) and in the "Kemi" (pine needle) sample are given together with the standard errors for the different digestion methods applied (Tab. III).

The HF and $\mathrm{HF}(\mathrm{DAC})$ procedures gave values nearer to the certified concentration for $\mathrm{Al}, \mathrm{Ca}, \mathrm{K}$ and $\mathrm{Zn}$. The $\mathrm{HNO}_{3}$, $\mathrm{HNO}_{3}+\mathrm{H}_{2} \mathrm{O}_{2}$ and $\mathrm{HNO}_{3}+\mathrm{HClO}_{4}$ procedures were somewhat ineffective at dissolving $\mathrm{Al}$ from the BCR CRM 100 and BCR CRM 101 reference samples. Mg also appeared to be rather difficult to dissolve by any of the acid procedures.

The acid procedures $\mathrm{HNO}_{3}+\mathrm{H}_{2} \mathrm{O}_{2}$ or $\mathrm{HNO}_{3}$ alone were suitable for $\mathrm{S}$. Especially $\mathrm{S}$, and to some extent also $\mathrm{Mg}$, were lost during the dry digestion (HF(DAC)). The $\mathrm{HNO}_{3}+\mathrm{HClO}_{4}$ digestion procedure in almost every case gave the lowest results compared to the other acid digestion procedures.

The concentration of $\mathrm{K}$ in BCR CRM 100 obtained after the $\mathrm{HNO}_{3}+\mathrm{HClO}_{4}$ digestion procedure was significantly lower than the certified value. The $\mathrm{HNO}_{3}+\mathrm{HClO}_{4}$ digestion procedure also gave a lower value for $\mathrm{K}$ in the "Kemi" pine needle sample than the other digestion procedures. This could be due to the precipitation of potassium perchlorate
Table III. Means $(n=3)$ and standard deviations $( \pm)$ of Al, Ca, K, $\mathrm{Mg}, \mathrm{Mn}, \mathrm{Zn}$ and $\mathrm{S}(\mathrm{mg} / \mathrm{kg})$ analysis of reference samples BCR CRM 100 (spruce needles) and BCR CRM 101 (beech leaves) and the "Kemi" pine needle sample $(n=1)$ compared with the certified values. Digestion procedures with different acid mixtures and analysis by ICP-AES or the Leco (IR combustion) method.

\begin{tabular}{|c|c|c|c|c|}
\hline Element & Procedure & BCR CRM 100 & BCR CRM 101 & "Kemi" \\
\hline \multirow[t]{6}{*}{ Al } & Certified value & $435 \pm 4$ & $173 \pm 5$ & -- \\
\hline & $\mathrm{HNO}_{3}$ & $207.6 \pm 3.1$ & $116.3 \pm 2.1$ & 145 \\
\hline & $\mathrm{HNO}_{3}+\mathrm{H}_{2} \mathrm{O}_{2}$ & $225.3 \pm 12.2$ & $126.3 \pm 1.5$ & 153 \\
\hline & $\mathrm{HNO}_{3}+\mathrm{HClO}_{4}$ & $163.7 \pm 5.5$ & $99.5 \pm 2.3$ & 135 \\
\hline & $\mathrm{HF}$ & $431.0 \pm 15.1$ & $202.0 \pm 5.6$ & 222 \\
\hline & HF (DAC) & $353.6 \pm 110.6$ & $213.3 \pm 20.0$ & 219 \\
\hline \multirow[t]{6}{*}{$\mathrm{Ca}$} & Certified value & $5300 \pm 50$ & $4280 \pm 80$ & -- \\
\hline & $\mathrm{HNO}_{3}$ & $5080.0 \pm 20.0$ & $4396.9 \pm 11.5$ & 2760 \\
\hline & $\mathrm{HNO}_{3}+\mathrm{H}_{2} \mathrm{O}_{2}$ & $4816.6 \pm 30.5$ & $4150.0 \pm 34.6$ & 2550 \\
\hline & $\mathrm{HNO}_{3}+\mathrm{HClO}_{4}$ & $4703.3 \pm 5.7$ & $4056.6 \pm 25.1$ & 2500 \\
\hline & $\mathrm{HF}$ & $4026.6 \pm 98.1$ & $3596.6 \pm 217.3$ & 2230 \\
\hline & $\mathrm{HF}$ (DAC) & $4330.0 \pm 373.2$ & $3763.3 \pm 111.5$ & 2230 \\
\hline \multirow[t]{6}{*}{$\mathbf{K}$} & Certified value & $9940 \pm 200$ & -- & -- \\
\hline & $\mathrm{HNO}_{3}$ & $9193.3 \pm 25.1$ & $6073.3 \pm 15.2$ & 5640 \\
\hline & $\mathrm{HNO}_{3}+\mathrm{H}_{2} \mathrm{O}_{2}$ & $9363.3 \pm 106.9$ & $6123.3 \pm 40.4$ & 5560 \\
\hline & $\mathrm{HNO}_{3}+\mathrm{HClO}_{4}$ & $8916.6 \pm 15.3$ & $5860.0 \pm 40.0$ & 5300 \\
\hline & $\mathrm{HF}$ & $9486.6 \pm 151.7$ & $6340.0 \pm 60.8$ & 5810 \\
\hline & $\mathrm{HF}$ (DAC) & $9616.6 \pm 168.0$ & $6430.0 \pm 177.7$ & 5820 \\
\hline \multirow[t]{6}{*}{ Mg } & Certified value & $878 \pm 17$ & $619 \pm 9$ & -- \\
\hline & $\mathrm{HNO}_{3}$ & $731.6 \pm 4.5$ & $515.3 \pm 11.9$ & 1100 \\
\hline & $\mathrm{HNO}_{3}+\mathrm{H}_{2} \mathrm{O}_{2}$ & $797.6 \pm 22.8$ & $564.3 \pm 10.0$ & 1210 \\
\hline & $\mathrm{HNO}_{3}+\mathrm{HClO}_{4}$ & $785.6 \pm 12.6$ & $557.3 \pm 2.0$ & 1180 \\
\hline & $\mathrm{HF}$ & $763.0 \pm 27.5$ & $541.0 \pm 27.0$ & 1080 \\
\hline & HF (DAC) & $763.0 \pm 13.7$ & $559.0 \pm 9.0$ & 1150 \\
\hline \multirow[t]{6}{*}{ Mn } & Certified value & -- & $915 \pm 11$ & -- \\
\hline & $\mathrm{HNO}_{3}$ & $1243.3 \pm 5.7$ & $857.3 \pm 5.8$ & 181 \\
\hline & $\mathrm{HNO}_{3}+\mathrm{H}_{2} \mathrm{O}_{2}$ & $1246.6 \pm 32.1$ & $866.6 \pm 4.1$ & 181 \\
\hline & $\mathrm{HNO}_{3}+\mathrm{HClO}_{4}$ & $1240.0 \pm 17.3$ & $858.3 \pm 2.5$ & 180 \\
\hline & $\mathrm{HF}$ & $1246.6 \pm 28.8$ & $67.3 \pm 5.5$ & 179 \\
\hline & $\mathrm{HF}(\mathrm{DAC})$ & $1266.6 \pm 28.8$ & $873.3 \pm 3.2$ & 175 \\
\hline \multirow[t]{6}{*}{$\mathbf{Z n}$} & Certified value & -- & $35.3 \pm 2.3$ & -- \\
\hline & $\mathrm{HNO}_{3}$ & $60.2 \pm 0.4$ & $29.9 \pm 0.3$ & 39.1 \\
\hline & $\mathrm{HNO}_{3}+\mathrm{H}_{2} \mathrm{O}_{2}$ & $62.4 \pm 1.7$ & $31.2 \pm 0.1$ & 40.7 \\
\hline & $\mathrm{HNO}_{3}+\mathrm{HClO}_{4}$ & $65.0 \pm 4.4$ & $31.8 \pm 0.4$ & 41.3 \\
\hline & $\mathrm{HF}$ & $68.1 \pm 1.4$ & $35.9 \pm 0.5$ & 46.0 \\
\hline & $\mathrm{HF}$ (DAC) & $67.7 \pm 1.6$ & $36.5 \pm 1.1$ & 46.7 \\
\hline \multirow[t]{6}{*}{$\mathbf{S}$} & Certified value & $2690 \pm 40$ & $1700 \pm 40$ & -- \\
\hline & $\mathrm{HNO}_{3}$ & $2496.6 \pm 5.7$ & $1560.0 \pm 20.0$ & 920 \\
\hline & $\mathrm{HNO}_{3}+\mathrm{H}_{2} \mathrm{O}_{2}$ & $2616.6 \pm 65.1$ & $1646.6 \pm 11.5$ & 978 \\
\hline & $\mathrm{HNO}_{3}+\mathrm{HClO}_{4}$ & $2240.0 \pm 26.4$ & $1400 \pm 26.4$ & 846 \\
\hline & $\mathrm{HF}$ & $2986.6 \pm 81.4$ & $1993.3 \pm 23.1$ & 1290 \\
\hline & HF (DAC) & $1333.3 \pm 40.4$ & $771.0 \pm 36.6$ & 359 \\
\hline $\begin{array}{l}\text { S } \\
\text { (Leco) }\end{array}$ & Combustion + IR & $2600 \pm 80$ & $1700 \pm 20.8$ & 1100 \\
\hline
\end{tabular}

during nitric/perchloric acid digestion, as has been reported in other studies [28-29]. 
The reproducibility of the individual elements in reference samples BCR CRM 100 and BCR CRM 101 were below $\pm 5 \%$ for almost every element in all of the acid procedures with ICP-AES and ICP-MS. Exceptions were HF(DAC) for Al from BCR CRM 100 and for Al from BCR CRM 101, HF(DAC) for Ca from BCR CRM 100, HF for $\mathrm{Ca}$ from BCR CRM 101 and $\mathrm{HNO}_{3}+\mathrm{HClO}_{4}$ for $\mathrm{Zn}$ from BCR CRM 100 with reproducibilities of 31.3, 9.3, 8.6, 6.0 and $6.7 \%$ respectively.

The results of elemental analysis of $\mathrm{Pb}, \mathrm{V}, \mathrm{Cr}, \mathrm{Cu}, \mathrm{Cd}$, $\mathrm{Ni}, \mathrm{Co}$ and $\mathrm{S}$ in reference sample HUMH2 (Organic Surface Soil) and "Tornio" (pine needles) are given, together with the standard errors, for the different digestion methods applied (Tab. IV).

$\mathrm{Cr}$, in particular, was extremely difficult to solubilise with the $\mathrm{HNO}_{3}+\mathrm{HClO}_{4}$ digestion procedure from the "Tornio" pine needle sample, as well as from the reference sample $\mathrm{HUMH} 2$. The $\mathrm{HNO}_{3}+\mathrm{HClO}_{4}$ digestion procedure gave about $30 \%$ lower values for $\mathrm{Cr}$ for reference sample HUMH2 than the $\mathrm{HNO}_{3}$ or $\mathrm{HNO}_{3}+\mathrm{H}_{2} \mathrm{O}_{2}$ digestion procedures. Acid procedures $\mathrm{HNO}_{3}$ and $\mathrm{HNO}_{3}+\mathrm{H}_{2} \mathrm{O}_{2}$ were suitable for dissolving reference sample $\mathrm{HUMH} 2$ because they gave exactly the same concentration for $\mathrm{Cr}$ as the certified value. The $\mathrm{HNO}_{3}+\mathrm{HClO}_{4}$ digestion procedure was also inefficient at dissolving $\mathrm{Cr}$ from the "Tornio" pine needle: about $72 \%$ and $66 \%$ lower $\mathrm{Cr}$ values than $\mathrm{HNO}_{3}$ or $\mathrm{HNO}_{3}+\mathrm{H}_{2} \mathrm{O}_{2}$ respectively. The acid procedures $\mathrm{HF}$ and $\mathrm{HF}(\mathrm{DAC})$ gave 1.6 and 1.4 times greater $\mathrm{Cr}$ values for reference sample HUMH2 and the uncertified "Tornio" pine needle sample, respectively. These results for the "Tornio" pine needle sample are probably due to the fact that dust emitted from the ferrochrome and steel works contains $\mathrm{FeO}$ $\mathrm{Cr}_{2} \mathrm{O}_{3}$, which is difficult to dissolve.

The $\mathrm{HNO}_{3}+\mathrm{HClO}_{4}$ digestion procedure, and especially the $\mathrm{HF}(\mathrm{DAC})$ digestion procedure, gave low recoveries for $\mathrm{S}$ and $\mathrm{Cu}$. This may be due to incomplete oxidation and to gaseous losses during the boiling stage in the $\mathrm{HNO}_{3}+\mathrm{HClO}_{4}$ digestion procedure. According to the results for reference sample $\mathrm{HUMH} 2$, the $\mathrm{HNO}_{3}$ and $\mathrm{HNO}_{3}+\mathrm{HClO}_{4}$ procedures were suitable for $\mathrm{V}, \mathrm{Ni}$ and $\mathrm{Co}$ determination, and the $\mathrm{HNO}_{3}$ and $\mathrm{HNO}_{3}+\mathrm{H}_{2} \mathrm{O}_{2}$ procedures for $\mathrm{S}$. The reproducibility for individual elements in reference samples HUMH2 determined by ICP were below $\pm 5 \%$, except for the $\mathrm{HNO}_{3}$ procedure for $\mathrm{Cr}$, which had reproducibility of $6.5 \%$.

The combustion technique with infrared (IR) detection also gave relatively good reproducibility for sulphur, since the accuracies for both the reference samples and "Kemi" and "Tornio" pine needle samples were in all cases within 1-3 \%. For unknown samples, i.e. the "Kemi" and "Tornio" pine needle samples, the ideal analytical approach would have been the use of at least two different methods, e.g. wetdigestion and non-destructive methods, such as XRF or NAA.

For ICP analysis, chemical dissolution is the first step in the analysis of solid samples. Losses in this stage of the
Table IV. Means $(n=3)$ and standard deviations $( \pm)$ of $\mathrm{Pb}, \mathrm{V}, \mathrm{Cr}$, $\mathrm{Cu}, \mathrm{Cd}, \mathrm{Ni}, \mathrm{Co}$ and $\mathrm{S}(\mathrm{mg} / \mathrm{kg})$ analysis of reference sample HUMH2 (organic surface soil) and the "Tornio" pine needle sample $(n=1)$ compared with certified values. Digestion procedures with different acid mixtures and analysis by ICP-AES or ICP-MS (*, when $n=1$ ) or the Leco (IR combustion) method.

\begin{tabular}{|c|c|c|c|}
\hline Element & Procedure & $H U M H 2$ & "Tornio" \\
\hline $\mathbf{P b}$ & $\begin{array}{l}\text { Certified value } \\
\mathrm{HNO}_{3} \\
\mathrm{HNO}_{3}+\mathrm{H}_{2} \mathrm{O}_{2} \\
\mathrm{HNO}_{3}+\mathrm{HClO}_{4} \\
\mathrm{HF} \\
\mathrm{HF} \text { (DAC) }\end{array}$ & $\begin{array}{c}71.2 \pm 3.7 \\
75.8 \pm 1.9 \\
76 \pm 1.7 \\
76.6 \pm 1.1 \\
87.6(*) \\
75.1\left(^{*}\right)\end{array}$ & $\begin{array}{c}-- \\
4.26(*) \\
4.32(*) \\
4.07 \\
4.42(*) \\
4.55(*)\end{array}$ \\
\hline $\mathbf{V}$ & $\begin{array}{l}\text { Certified value } \\
\mathrm{HNO}_{3} \\
\mathrm{HNO}_{3}+\mathrm{H}_{2} \mathrm{O}_{2} \\
\mathrm{HNO}_{3}+\mathrm{HClO}_{4} \\
\mathrm{HF} \\
\mathrm{HF} \text { (DAC) }\end{array}$ & $\begin{array}{c}6.82 \pm 0.67 \\
7.6 \pm 0.3 \\
8.3 \pm 0.3 \\
6.7 \pm 0.2 \\
7.5(*) \\
7.4(*)\end{array}$ & $\begin{array}{c}-- \\
1.69(*) \\
1.62(*) \\
0.83 \\
2.11(*) \\
2.22(*)\end{array}$ \\
\hline $\mathrm{Cr}$ & $\begin{array}{l}\text { Certified value } \\
\mathrm{HNO}_{3} \\
\mathrm{HNO}_{3}+\mathrm{H}_{2} \mathrm{O}_{2} \\
\mathrm{HNO}_{3}+\mathrm{HClO}_{4} \\
\mathrm{HF} \\
\mathrm{HF} \text { (DAC) }\end{array}$ & $\begin{array}{c}4.46 \pm 0.85 \\
4.6 \pm 0.3 \\
4.4 \pm 0.2 \\
3.1 \pm 0.1 \\
7.5(*) \\
6.2(*)\end{array}$ & $\begin{array}{c}-- \\
266\left(^{*}\right) \\
223(*) \\
75.6 \\
437\left(^{*}\right) \\
426\left(^{*}\right)\end{array}$ \\
\hline $\mathrm{Cu}$ & $\begin{array}{l}\text { Certified value } \\
\mathrm{HNO}_{3} \\
\mathrm{HNO}_{3}+\mathrm{H}_{2} \mathrm{O}_{2} \\
\mathrm{HNO}_{3}+\mathrm{HClO}_{4} \\
\mathrm{HF} \\
\mathrm{HF} \text { (DAC) }\end{array}$ & $\begin{array}{c}401 \pm 20 \\
431 \pm 3.5 \\
418 \pm 2.5 \\
436 \pm 2.8 \\
382(*) \\
368(*)\end{array}$ & $\begin{array}{c}-- \\
5.55(*) \\
5.47(*) \\
<10 \\
5.22(*) \\
7.55(*)\end{array}$ \\
\hline Cd & $\begin{array}{l}\text { Certified value } \\
\mathrm{HNO}_{3} \\
\mathrm{HNO}_{3}+\mathrm{H}_{2} \mathrm{O}_{2} \\
\mathrm{HNO}_{3}+\mathrm{HClO}_{4} \\
\mathrm{HF} \\
\mathrm{HF} \text { (DAC) }\end{array}$ & $\begin{array}{c}1.66 \pm 0.05 \\
1.7 \pm 0.04 \\
1.6 \pm 0.03 \\
1.6 \pm 0.01 \\
1.5(*) \\
1.7(*)\end{array}$ & $\begin{array}{c}-- \\
0.17(*) \\
0.15(*) \\
<0.15 \\
0.15(*) \\
0.16(*)\end{array}$ \\
\hline $\mathbf{N i}$ & $\begin{array}{l}\text { Certified value } \\
\mathrm{HNO}_{3} \\
\mathrm{HNO}_{3}+\mathrm{H}_{2} \mathrm{O}_{2} \\
\mathrm{HNO}_{3}+\mathrm{HClO}_{4} \\
\mathrm{HF} \\
\mathrm{HF} \text { (DAC) }\end{array}$ & $\begin{array}{c}90 \pm 6 \\
94.9 \pm 2.6 \\
95.4 \pm 1.3 \\
90.3 \pm 0.6 \\
99.5 \pm 0.5 \\
95.8 \pm 1.6\end{array}$ & $\begin{array}{l}-- \\
46.5 \\
45.8 \\
37.8 \\
57.6 \\
53.8\end{array}$ \\
\hline Co & $\begin{array}{l}\text { Certified value } \\
\mathrm{HNO}_{3} \\
\mathrm{HNO}_{3}+\mathrm{H}_{2} \mathrm{O}_{2} \\
\mathrm{HNO}_{3}+\mathrm{HClO}_{4} \\
\mathrm{HF} \\
\mathrm{HF} \text { (DAC) }\end{array}$ & $\begin{aligned} & 7.69 \pm 0.25 \\
& 7.58 \pm 0.30 \\
& 7.51 \pm 0.12 \\
& 7.67 \pm 0.04 \\
&-- \\
&--\end{aligned}$ & $\begin{array}{l}-- \\
0.71 \\
0.87 \\
0.95 \\
-- \\
--\end{array}$ \\
\hline $\mathbf{S}$ & $\begin{array}{l}\text { Certified value } \\
\mathrm{HNO}_{3} \\
\mathrm{HNO}_{3}+\mathrm{H}_{2} \mathrm{O}_{2} \\
\mathrm{HNO}_{3}+\mathrm{HClO}_{4} \\
\mathrm{HF} \\
\mathrm{HF} \text { (DAC) }\end{array}$ & $\begin{array}{c}1710 \pm 100 \\
1606 \pm 28.8 \\
1653 \pm 11.5 \\
1543 \pm 11.5 \\
1870 \pm 26.4 \\
526 \pm 17.4\end{array}$ & $\begin{array}{c}-- \\
1090 \\
1140 \\
994 \\
1510 \\
454\end{array}$ \\
\hline S (Leco) & Combustion + IR & $1776.7 \pm 15.3$ & 1100 \\
\hline
\end{tabular}




\section{Original articles}

analysis will obviously affect the accuracy of the final results. There are number of possible loss mechanisms during sample digestion, including gaseous evolution, absorption or adsorption onto surfaces, precipitation and persistence of undissolved material. Plant materials are also known to contain a range of soil and/or mineral fractions, and thus may be difficult to dissolve. Although this study was not designed to determine possible loss mechanisms, the results showed that the sample digestion procedure is critical for obtaining accurate results.

\section{Conclusion}

The results of this study indicate that microwave dissolution combined with ICP-AES or ICP-MS determination is a very rapid and accurate method for analysing botanical matrices. The effect of different acid mixtures and digestion procedures on the accuracy of analysis must, in any case, be known. A careful choice of suitable digestion procedures for plant material is of great importance in ensuring that correct results are obtaining in the determination of trace elements by a range of analytical methods, e.g. ICP-AES. Validation of the digestion procedure only, usually by means of CRMs, may sometimes lead to erroneous evaluation because even very similar materials (matrices) may exhibit different behaviour during the digestion. In addition to ICP-AES, the combustion technique combined with infrared (IR) detection also gave relatively good reproducibility for sulphur determinations.

\section{Acknowledgements}

Special thanks are due to members of the advisory team of the bioindicator project, Dr. Hannu Nurmesniemi, Veli-Antti Kivilinna M.Sc., and Aapo Mäenpää M.Sc. for their valuable advice during the course of the study. Mr. Kari Lumpus helped in the field work by collecting pine needle samples. The authors wish to thank the technical staff of the Geological Survey of Finland, especially Heikki Niskavaara M.S., Meeri Suominen M.Sc., and Mrs Mervi Wiik under whose supervision all the chemical analyses were performed. We wish to thank also Mr. John Derome for correcting the English language. This study was supported by Oy Metsä-Botnia Ab Kemi Mills and StoraEnso Oyj Veitsiluoto Mills.

\section{References}

1. Huttunen, S.; Laine, K.; Torvela, H. Ann. Bot. Fennici. 1985 , 22, 343-359.
2. Boguslaw, M.; Bytnerowicz, A.; Dmuchowski, W. Aquilo Ser. Bot. 1983, 19, 326-331.

3. Laamanen, A.; Lahdes, R. Work Environmental Health 1969, $6,41-43$.

4. Määttänen, J. In Environmental effects of a pulp mill in North Karelia. The perspective of environmental geography; Thesis, University of Joensuu at Finland, 1999.

5. Tabatabai, M.A.; Bremner, J.M. Agron. J. 1970, 62, 805-806.

6. Basson, W.D.; Bohmer, R.G. Analyst (London) 1972, 97, 266270.

7. Morante, C. Analytica Chimica Acta 1991, 249, 479-488.

8. Tomassini, F.D.; Puckett, K.J.; Nieboer, E.; Richardson, D.H.S.; Grace, B. Can. J. Bot. 1976, 54, 1591-1603.

9. Alexander, G.V. Anal. Chem. 1965, 37, 1671-1674.

10. Norrish, K.; Hutton, J.T. X-Ray Spectom. 1977, 6, 6-17.

11. Tiedemann, A.R.; Anderson, T.D. Plant Soil 1971, 35, 197200.

12. Jones, J.B.; Isaac, R.A. J. Agric. Food Chem. 1972, 20, 12921294.

13. Bartels, U.; Pham, T.T. Fresenius'Z. Anal.Chem. 1982, 310, 13-15.

14. Hern, J.L. Commun. Soil Sci. Plant Anal. 1984, 15, 99-109.

15. Greenfield, S.; Jones, I, Li.; Berry, C.T. Analyst. 1964, 89, 713-720.

16. Wendt, R.H.; Fassel, V.A. Anal.Chem. 1965, 37(7), 368-283.

17. Lamle, K.J.; Hill, S.J. Analyst. 1998, 123, (103R-133R).

18. Montaser, A.; Golightly, D. W. In Inductively Coupled Plasmas in Analytical Atomic Spectrometry; New York: VCH Publishers, Inc., Second Edition, 1992, pp 1017 and references cited therein.

19. Niskanen, I.; Witick, A. Technical report No: 22, 1999, Ympäristöntutkimuskeskus, Jyväskylä (in Finnish).

20. Vanhatalo, M. Technical report No 3, 1989, Kemin kaupunki, ympäristönsuojelujulkaisu, Kemi. (in Finnish).

21. Tynnyrinen, S. Technical report, 1993, Kuusen neulaset ilman epäpuhtauksien bioindikaattoreina Kemira Oy:n Siilinjärven tehtaiden ja kaivoksen ympäristössä, University of Kuopio, Finland (in Finnish).

22. Tiedemann, A.; Anderson, T.D. Plant Soil. 1971, 35, 197-200.

23. Jones, J.B.; Isaac, R.A. J. Agric. Food Chem. 1972, 20, $1292-$ 1294.

24. Bartels, U.; Pham, T.T. Fresenius' Z. Anal. Chem. 1982, 310, 13-15.

25. Hern, J.L. Commun. Soil Sci. Plant Anal. 1984, 15, 99-109.

26. SFS 5781. Air protection. Bioindication. Determination of sulphur concentrations in conifer needles using ICP emission spectrophotometer (in Finnish).

27. US EPA Method 3051. Microwave assisted acid digestion of sediments, sludges, soils and oils.

28. Anderson, D.L.; Henderson, L.J. Agronomy Journal. 1988, 80, 549-552.

29. Zarcinas, B.A. Divisional Report No. 70, 1984, Commonwealth Scientific and Industrial Research Organization, Australia. 